\title{
CONVENTIONAL ROOM EFFECTIVENESS TEST USING RAYSAFE IN RADIOLOGY UNIT SITI RAHMAH ISLAMIC HOSPITAL PADANG
}

\author{
*Nerifa Dewilza', Sagita Yudha', Widya Alfareza ${ }^{1}$ \\ 1Baiturrahmah University Padang \\ `nerifadewilza@atro.unbrah.ac.id, sagitayudha@atro.unbrah.ac.id, widyaalfareza@gmail.com
}

Submitted : 20 November 2021 . Accepted : 15 Januari 2022 . Published : 27 Januari 2022

\begin{abstract}
The more the number of patients, the greater the number the examination was carried out in the radiology room at the Siti Islamic Hospital Rahmah. This research aims to determine the effectiveness and level of security in conventional spaces Radiology Unit of Siti Rahmah Islamic Hospital against radiation with use raysafe unfors. This research was conducted by sticking raysafe unfors from the inside and the outside on walls, doors and $\mathrm{Pb}$ glass in a conventional room in the Hospital Radiology Unit Islam Siti Rahmah with the type of quantitative research. The results of the measurement of the largest dose rate were found at the inner $3 \mathrm{~A}$ point, which was $10.5198 \mathrm{mGy} / \mathrm{h}$. While the results of the measurement of the smallest dose rate are at the outer 7B point, which is $-0.0001 \mathrm{mGy} / \mathrm{h}$. The dose before penetrating the material (D0) measured in a conventional room ranged from $10.5198-1.3228 \mathrm{mGy} / \mathrm{h}$. The dose value that varies at the measurement point is caused by the distance of the radiation source from the measurement point. Where in the conventional room (D0), the largest measured radiation dose is at point $3 \mathrm{~A} 10.5198 \mathrm{mGy} / \mathrm{h}$. This is because the measurement position is closest to the radiation source with a distance of $160 \mathrm{~cm}$. Conventional space buildings are already effective against scattered radiation and safe as a radiation barrier with the effectiveness of values ranging from $99.9 \%$ to $100 \%$. The results showed that the ability of walls, doors and $\mathrm{Pb}$ in a conventional room in the Radiology Unit of the Siti Rahmah Islamic Hospital absorb radiation.
\end{abstract}

Keyword : Effectiveness Test; Conventional Room; Unfors Raysafe.

\section{BACKGROUND}

Siti Rahmah Islamic Hospital is a health service center in the city of Padang which has a fairly complete radiology aircraft such as X-rays, ultrasound, MRI, CT-Scan, Panoramic and Mammography. The radiology room at the Siti Rahmah Islamic Hospital is commonly used for examination of the extremities, cranium, thorax, thoracolumbar, lumbosacral, abdomen, pelvis, and appendicogram. The more the number of patients, the more the number of examinations carried out in the radiology room at the Siti Rahmah Islamic Hospital.

The size of the conventional examination room according to the Regulation of the Head of the Nuclear Energy Supervisory Agency Number 8 of 2011 must be $4 \mathrm{~m} \times 3 \mathrm{~m} \times 2.8 \mathrm{~m}$, the walls of the room are made of red brick with a thickness of $25 \mathrm{~cm}$ or equivalent to $2 \mathrm{~mm}$ of lead $(\mathrm{Pb})$, the door of the room must be coated with lead with a certain thickness. The Radiology Unit has many rooms adjacent to conventional examination rooms including the control panel room, officer guard room, administration and patient waiting room so that the room must be safe from radiation. The use of radiation sources in various fields, especially in the world of health, continues to grow and increase from time to time. The utilization includes radiodiagnostic measures, radiotherapy, and nuclear medicine (Akhadi, 2000). These three services use radioactive sources which are very dangerous if not used in accordance with established safety standards. However, in terms of its benefits, it is very useful in the health sector, especially for diagnosing passive diseases. In the utilization of radiation sources, the human safety factor must be given top priority, so that its utilization will be more perfect if the loss factor that will arise can be reduced as low as possible or eliminated altogether (Akhadi, 2000). The radiation source room must be built according to radiology room building standards, which is to have an effective wall as a radiation barrier made of $\mathrm{Pb}$ and concrete, where these materials can weaken the intensity of radiation, the point is to minimize the dangers or effects of radiation that will arise (Sari, 2010). ).

Siti Rahmah Islamic Hospital is a health service center in the city of Padang which has a large number of patients. The more the number of patients, the more the number of examinations carried out in the radiology room 
at the Siti Rahmah Islamic Hospital. In the West Sumatra region in recent years, earthquakes have often occurred which cause shifts in buildings, especially in special buildings such as the walls of conventional rooms at the Radiology Unit of the Siti Rahmah Islamic Hospital, this is indicated by the presence of cracks which if a leak occurs, the dose received by the community The surrounding area and radiation officers will increase, but this room has never been tested for the effectiveness or accuracy of the scattering radiation.

\section{METHODE}

This type of research is quantitative with an experimental method of measuring exposure to X-ray radiation doses around conventional rooms at the Radiology of Siti Rahmah Islamic Hospital using an unfors Raysafe measuring instrument. Measurements were made at 7 points by attaching Raysafe indoors and outdoors at each point. This research was conducted in July 2020 (Soekidjo, 2012). The research time was carried out for 1 day by attaching Raysafe at each predetermined point. After exposure, Raysafe will read the dose rate in $\mathrm{mGy} / \mathrm{h}$ units. Before exposing the 7 points, the background value reading at the Radiology Unit of the Siti Rahmah Islamic Hospital is $0.000002 \mathrm{mGy} / \mathrm{h}$. The tools and materials used in this study were Unfors raysef $\mathrm{Xi}$ and an X-ray plane.

\section{RESULT AND DISCUSSION}

Based on research that has been carried out in the conventional aircraft room at the radiology unit of the Siti Rahmah Islamic Hospital in July 2020 to determine the effectiveness of the conventional aircraft room in the Radiology Unit of the Siti Rahmah Islamic Hospital in resisting radiation generated by conventional X-ray aircraft. The measuring instrument used by Raysafe can be obtained about the Effectiveness of Conventional Aircraft Room at the Radiology Unit of the Siti Rahmah Islamic Hospital.

The research time was carried out for 1 day by attaching Raysafe at each predetermined point. After exposure, Raysafe will read the dose rate in $\mathrm{mGy} / \mathrm{h}$ units. Before exposing the 7 points, the background value reading at the Radiology Unit of the Siti Rahmah Islamic Hospital is $0.000002 \mathrm{mGy} / \mathrm{h}$. The results of the dose rate measurement are as follows:

\section{At points $1 \mathrm{~A}$ and $1 \mathrm{~B}$}

a. On the wall before passing through the radiation barrier $(1 \mathrm{~A})$

Measurement Results - Background

$4.960 \mathrm{mG} / \mathrm{h}-0.0002 \mathrm{mGy} / \mathrm{h}=4.9598 \mathrm{mGy} / \mathrm{h}$

b. On the wall after passing through the radiation barrier (1B)

Measurement Results - Background

$0.0002 \mathrm{mGy} / \mathrm{h}-0.0002 \mathrm{mGy} / \mathrm{h}=0.0000 \mathrm{mGy} / \mathrm{h}$

2. At points $2 \mathrm{~A}$ and $2 \mathrm{~B}$

a. On the wall before passing through the radiation barrier $(2 \mathrm{~A})$

Measurement Results - Background

$2.273 \mathrm{mGy} / \mathrm{h}-0.0002 \mathrm{mGy} / \mathrm{h}=2.2728 \mathrm{mGy} / \mathrm{h}$

b. On the wall after passing through the radiation barrier (2B)

Measurement Results - Background

$0.0000 \mathrm{mGy} / \mathrm{h}-0.0002 \mathrm{mGy} / \mathrm{h}=-0.0002 \mathrm{mGy} / \mathrm{h}$

3. At points $3 \mathrm{~A}$ and $3 \mathrm{~B}$

a. On the wall before passing through the radiation barrier ( $3 A$ )

Measurement Results - Background

$10.52 \mathrm{mGy} / \mathrm{h}-0.0002 \mathrm{mGy} / \mathrm{h}=10.5198 \mathrm{mGy} / \mathrm{h}$

b. On the wall after passing through the radiation barrier (3B)

Measurement Results - Background

$0.0002 \mathrm{mGy} / \mathrm{h}-0.0002 \mathrm{mGy} / \mathrm{h}=0.0000 \mathrm{mGy} / \mathrm{h}$

4. At points $4 \mathrm{~A}$ and $4 \mathrm{~B}$

a. On the wall before passing through the radiation barrier (4A)

Measurement Results - Background

$3.283 \mathrm{mGy} / \mathrm{h}-0.0002 \mathrm{mG} / \mathrm{h}=3.2828 \mathrm{mG} / \mathrm{h}$

b. On the wall after passing through the radiation barrier (4B)

Measurement Results - Background

$0.0000 \mathrm{mGy} / \mathrm{h}-0.0002 \mathrm{mGy} / \mathrm{h}=-0.0002 \mathrm{mG} / \mathrm{h}$ 
5. At points $5 \mathrm{~A}$ and $5 \mathrm{~B}$

a. At the patient entrance before passing through the radiation barrier $(5 \mathrm{~A})$

Measurement Results - Background

$2.117 \mathrm{mGy} / \mathrm{h}-0.0002 \mathrm{mGy} / \mathrm{h}=2.1168 \mathrm{mG} / \mathrm{h}$

b. At the patient entrance after passing through the radiation barrier (5B)

Measurement Results - Background

$0.0000 \mathrm{mGy} / \mathrm{h}-0.0002 \mathrm{mGy} / \mathrm{h}=-0.0002 \mathrm{mGy} / \mathrm{h}$

6. At points $6 \mathrm{~A}$ and $6 \mathrm{~B}$

a. On the $\mathrm{Pb}$ Glass before passing through the radiation barrier $(6 \mathrm{~A})$

Measurement Results - Background

$1.804 \mathrm{mGy} / \mathrm{h}-0.0002 \mathrm{mGy} / \mathrm{h}=1.8038 \mathrm{mGy} / \mathrm{h}$

b. On the Pb Glass after passing through the radiation barrier (6B)

Measurement Results - Background

$0.0000 \mathrm{mGy} / \mathrm{h}-0.0002 \mathrm{mG} / \mathrm{h}=-0.0002 \mathrm{mGy} / \mathrm{h}$

7. At points $7 \mathrm{~A}$ and $7 \mathrm{~B}$

a. On the control panel door before passing through the radiation barrier $(6 \mathrm{~A})$

Measurement Results - Background

$1.323 \mathrm{mGy} / \mathrm{h}-0.0002 \mathrm{mGy} / \mathrm{h}=1.3228 \mathrm{mGy} / \mathrm{h}$

b. On the control panel door after passing through the radiation barrier (6B)

Measurement Results - Background

$0.0001 \mathrm{mGy} / \mathrm{h}-0.0002 \mathrm{mGy} / \mathrm{h}=-0.0001 \mathrm{mG} / \mathrm{h}$

Table 1. The results of the measurement of the absorbed dose rate at each observation point in the Radiology Unit of the Siti Rahmah Islamic Hospital

\begin{tabular}{cccc}
\hline Location of Raysafe & Absorbed dose rate mGy/h & Background & Effective absorbed dose rate mGy/h \\
\hline Point 1A & 4,960 & 0,0002 & 4,9598 \\
Point 1B & 0,0002 & 0,0002 & 0,0000 \\
Point 2A & 2,273 & 0,0002 & 2.2728 \\
Point 2B & 0,0000 & 0,0002 & $-0,0002$ \\
Point 3A & 10,52 & 0,0002 & 10,5198 \\
Point 3B & 0,0002 & 0,0002 & 0,0000 \\
Point 4A & 3,283 & 0,0002 & 3,2828 \\
Point 4B & 0,0000 & 0,0002 & $-0,0002$ \\
Point 5A & 2,117 & 0,0002 & 2,1168 \\
Point 5B & 0,0000 & 0,0002 & $-0,0002$ \\
Point 6A & 1,804 & 0,0002 & 1,8038 \\
Point 6B & 0,0000 & 0,0002 & $-0,0002$ \\
Point 7A & 1,323 & 0,0002 & 1,3228 \\
Point 7B & 0,0001 & 0,0002 & $-0,0001$
\end{tabular}

\section{Room Effectiveness Calculation}

Effectiveness is a shield used to reduce the intensity of electromagnetic radiation to half or more of the original intensity of electromagnetic radiation. From the data obtained, according to Akhadi (2000), to test the effectiveness of the radiation barrier in an examination room, it can be determined by the following formula:

Effectiveness $=(\mathrm{D} 0-\mathrm{D}) / \mathrm{D} 0 \times 100$ Equation 
Description :

$\mathrm{D} 0=$ rate of radiation dose before passing through radiation barrier

$\mathrm{D}=$ radiation dose rate after passing through the radiation barrier

To test the effectiveness of the conventional room at the Radiology Unit of the Siti Rahmah Islamic Hospital as follows:

A. Point 1

Effectiveness $=(\mathrm{D} 0-\mathrm{D}) / \mathrm{D} 0 \times 100 \%$

$=(4.9598-0.0000) / 4.9598 \times 100 \%$

$=100 \%$

B. Point 2

Effectiveness $=(D 0-D) / D 0 \times 100 \%$

$=(2.2728-0.0002) / 2.2728 \times 100 \%$

$=100 \%$

C. Point 3

Effectiveness $=(\mathrm{D} 0-\mathrm{D}) / \mathrm{D} 0 \times 100 \%$

$=(10.5198-0.0000) / 10.5198 \times 100 \%$

$=100 \%$

D. Point 4

Effectiveness $=(D 0-D) / D 0 \times 100 \%$

$=(3.2828-0.0002) / 3.2828 \times 100 \%$

$=100 \%$

E. 5 point

Effectiveness $=(D 0-D) / D 0 \times 100 \%$

$=(2.1168-0.0002) / 2,1168 \times 100 \%$

$=100 \%$

F. Point 6

Effectiveness $=(\mathrm{D} 0-\mathrm{D}) / \mathrm{D} 0 \times 100 \%$

$=(1.8038-0.0002) / 1.8038 \times 100 \%$

$=100 \%$

G. Point 7

Effectiveness $=(D 0-D) / D 0 \times 100 \%$

$=(1.3228-0.0001) / 1.3228 \times 100 \%$

$=100 \%$

Table 2. The results of measuring the absorbed dose rate on each side of the conventional aircraft room at the Radiology Unit of the Siti Rahmah Islamic Hospital

\begin{tabular}{llll}
\hline Location of Raysafe & Dose rate beforeD0 $(\mathrm{mGy} / \mathrm{h})$ & Dose rate after D (mGy/h) & $\begin{array}{l}\text { Absorbed dose rate } \\
(\mathrm{DO}-\mathrm{D})\end{array}$ \\
\hline Point 1 & 4,9598 & 0,0000 & 4,9598 \\
Point 2 & 2,2728 & $-0,0002$ & 2,273 \\
Point 3 & 10,5198 & 0,0000 & 10,5198 \\
Point 4 & 3,2828 & $-0,0002$ & 3,2828 \\
Point 5 & 2,1168 & $-0,0002$ & 2,1168 \\
Point 6 & 1,8038 & $-0,0002$ & 1,8038 \\
Point 7 & 1,3228 & $-0,0001$ & 1,3228 \\
\hline
\end{tabular}


The results of measuring the effectiveness of conventional aircraft rooms at the Siti Rahmah Islamic Hospital Unit can be seen in table 4 below:

Table 3. Results of measuring the effectiveness of conventional aircraft rooms in the Siti Rahmah Islamic Hospital Unit.

\begin{tabular}{ccccc}
\hline Location of Raysafe & D0 & D & Effectiveness & Description \\
\hline Point 1 & 4,9598 & 0,0000 & $100 \%$ & Effective \\
Point 2 & 2,2728 & $-0,0002$ & $100 \%$ & Effective \\
Point 3 & 10,5198 & 0,0000 & $100 \%$ & Effective \\
Point 4 & 3,2828 & 0,0002 & $99,9 \%$ & Effective \\
Point 5 & 2,1168 & $-0,0002$ & $99,9 \%$ & Effective \\
Point 6 & 1,8038 & $-0,0002$ & $100 \%$ & Effective \\
Point 7 & 1,3228 & 0,0001 & $100 \%$ & Effective \\
\hline
\end{tabular}

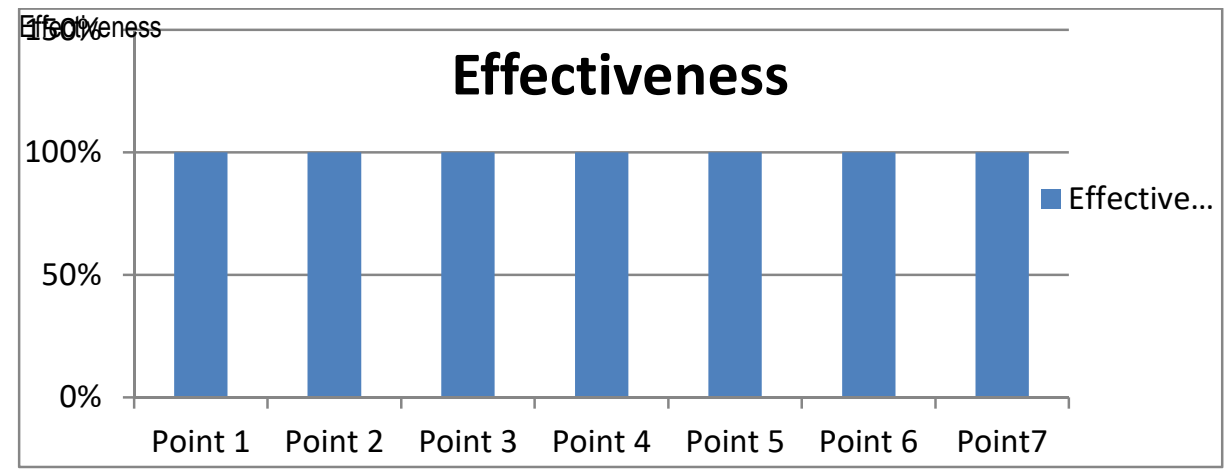

From the table above, the effectiveness of conventional room buildings has been effective as a radiation barrier, the TVT concept is an effective radiation barrier that is able to reduce the intensity of electromagnetic radiation to $1 / 10$ of the original intensity (Akhadi, 2000). Table 4 shows that the results of the largest dose rate measurement are at the inner $3 \mathrm{~A}$ point, which is $10.5198 \mathrm{mGy} / \mathrm{h}$. While the results of the measurement of the smallest dose rate are at the outer $7 \mathrm{~B}$ point, which is $-0.0001 \mathrm{mGy} / \mathrm{h}$. The dose before penetrating the material (D0) measured in a conventional room ranged from $10.5198-1.3228 \mathrm{mGy} / \mathrm{h}$. The dose value that varies at the measurement point is caused by the distance of the radiation source from the measurement point. Where in the conventional room (D0), the largest measured radiation dose is at point $3 A 10.5198 \mathrm{mGy} / \mathrm{h}$. This is because the measurement position is closest to the radiation source with a distance of $160 \mathrm{~cm}$.

Then the closer the distance of the radiation source and the measurement point, the greater the dose value and vice versa. The dose after penetrating the material $(D)$ measured in a conventional chamber is in the range of $0.0000--0.0001 \mathrm{mGy} / \mathrm{h}$. The dose value that varies at the measurement point is due to the distance factor from the measurement point. Where in the conventional outdoor area $(\mathrm{D})$ the smallest measured area is at point $7 \mathrm{~B}$ - 
$0.0001 \mathrm{mGy} / \mathrm{h}$. This is because the measurement position is farthest from the radiation source with a distance of $455 \mathrm{~cm}$. The farther away the measurement point is, the smaller the dose value.

Measurement of radiation dose in conventional aircraft rooms at Siti Rahmah Islamic Hospital is influenced by several factors, one of which is the distance and thickness of the radiation shield, where the farther the radiation source is to the measurement point, the smaller the radiation dose and the closer the radiation source is to the measurement point. then the measured radiation dose will be greater, while for radiation shielding the thicker the shield used, the higher the absorbed dose will be, and vice versa if the radiation shield is thinner, the absorbed radiation will be smaller (Permenkes, 2008).

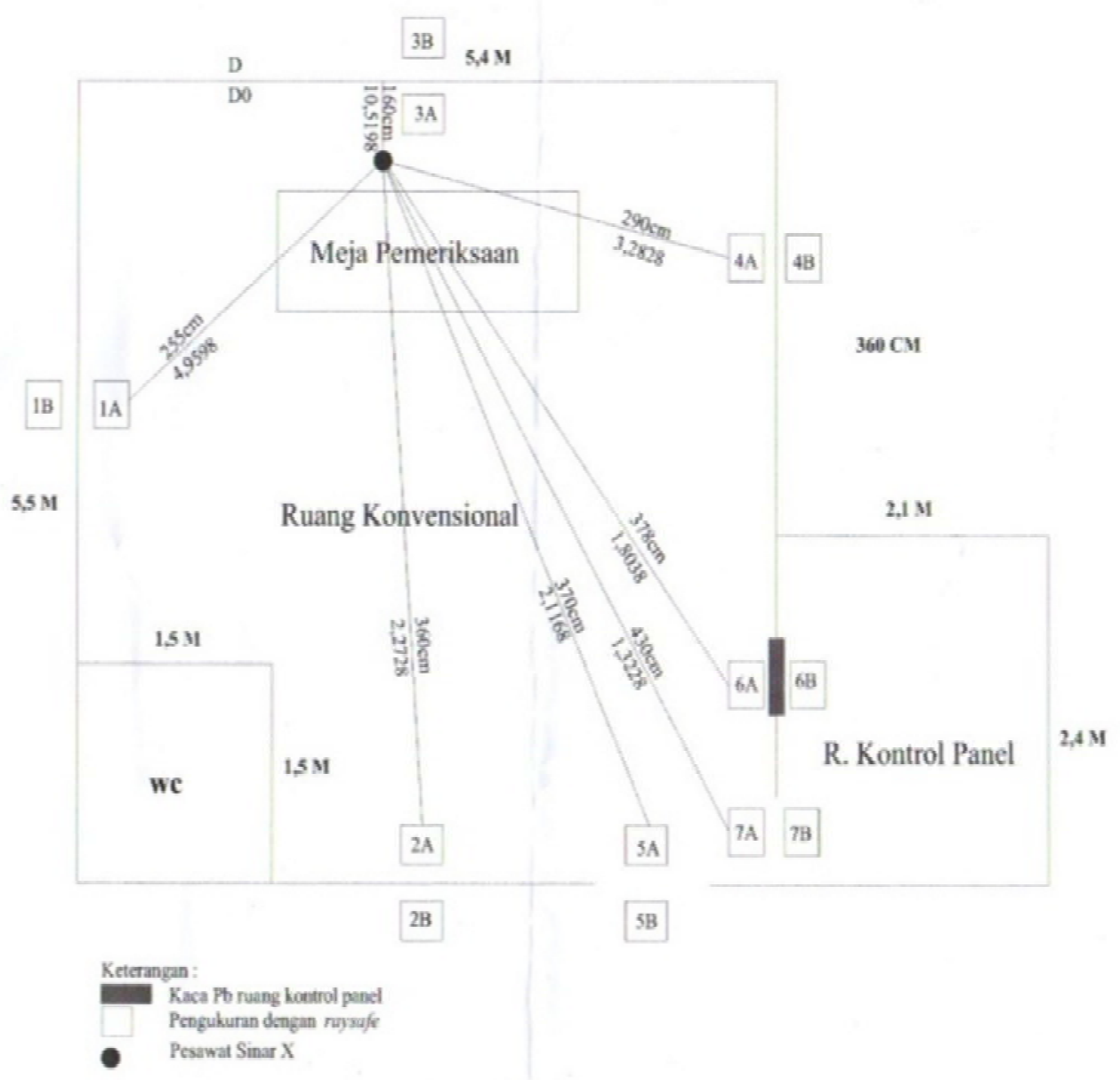

Figure 1. Schematic of the distance between Raysafe points

Based on research that has been carried out by researchers who are also collaborating with Fluke Biomedical at the Siti Rahmah Islamic Hospital Unit on the Conventional Room Effectiveness test against radiation doses, the results are $100 \%$ effective on the left wall, $100 \%$ administration wall, $100 \%$ mammography wall, and control wall. $100 \%$ panel, $100 \%$ patient door, $100 \% \mathrm{~Pb}$ Glass and $100 \%$ control panel door.

From these results, the effectiveness of the conventional room building has been effective as a radiation barrier because according to Akhadi (2000) the concept of TVT is an effective radiation barrier which is able to reduce the intensity of electromagnetic radiation to $1 / 10$ of the original intensity. According to Rudi, et al (2012) concluded that the closer the measurement point is to the radiation source, the larger the radiation dose received, to prevent radiation reception, it is done by keeping a safe distance from the radiation source. 


\section{CONCLUSIONS AND SUGGESTIONS}

Based on the results of research on the Conventional Room Effectiveness Test at the Siti Rahmah Islamic Hospital Unit using the Raysafe tool, the following conclusions can be drawn: Radiology conventional examination room at Siti Rahmah Islamic Hospital is able to absorb scattered radiation and is effective as a radiation barrier with $100 \%$ effectiveness, The walls of the Radiology Conventional Examination Room at the Siti Rahmah Islamic Hospital are able to absorb scattered radiation and are effective as a radiation barrier with $100 \%$ effectiveness, The PB glass and the door in the control panel room are able to absorb scattered radiation with $100 \%$ effectiveness, and the door in the examination room is able to absorb scattered radiation effectively as a radiation barrier with $100 \%$ effectiveness.

The conventional room at the Radiology Unit of the Siti Rahmah Islamic Hospital has been said to be effective and in accordance with the Conventional room building standards set by the head of BAPETEN Regulation No. 8 of 2011, but it is better to repair the cracks on the side of the wall of the room and the officers hope to be careful in working with radiation sources.

\section{REFERENCE}

Akhadi, M. (2000) Dasar-Dasar Proteksi Rsdiasi. Jakarta: Rineka Cipta.

Permenkes (2008) 'Keputusan Mentri Kesehatan Republik Indonesia (2008) 'Keputusan Mentri Kesehatan Republik Indonesia Nomor 1014 / Menkes / Sk / XI / 2008, Standar Pelayanan Radiologi Diagnostik di Sarana Pelayanan Kesehatan.'

Prof.Dr.Soekidjo, N. (2012) Metodologi Penelitian Kesehatan. Jakarta: Rineka Cipta.

Sari, O. P. (2010) Fisika Radiasi. Padang: Universitas Baiturrahmah.

Rasad, Sjhriar, dkk. 1998 Radiologi Diagnostik. Jakarta: Balai penerbitan FKUI

Rahman, Nova. (2009). Radiofotografi. Padang: Universitas Baitrahmah

Rudi, dkk (2012) Pengukuran Paparan Radiasi Pesawat Sinar-X di Instalasi Radiodiagnostik untuk Proteksi Radiasi

Jodoatmojo, S dkk. (1994). Petugas Proteksi Radiasi.Jakarta : Badan Tenaga Atom Nasional Pusat Pendidikan dan Penelitian.

Keputusan Kepala BAPETEN No. 1 tahun 1999 tentang ketentuan keselamata kerja terhadap radiasi.

Dwinanto, B. (2010) Teknik Radiography Kepala. Padang: Universita Baiturahmah SNI 18-6480-2000, Timah (Pb) Merupakan jenis plat logam yang direkomendasikan untuk proteksi radiasi gamma dan sinar-X 